\title{
STRATEGI PENGEMBANGAN AGRIBISNIS BUAH NAGA ORGANIK DI KABUPATEN WONOGIRI
}

\author{
Sabila Ajeng Paundrianagari ${ }^{* 1}$, Nuning Setyowati ${ }^{1}$, Rr. Aulia Qonita ${ }^{1}$ \\ ${ }^{1}$ Program Studi Agribisnis Fakultas Pertanian; Universitas Sebelas Maret Surakarta \\ Email:sabilaajengp@gmail.com
}

\begin{abstract}
The research aimed to identify internal factors that become strengths and weaknesses as well as external factors that become opportunities and threats, formulate alternative development strategies, and formulate priority strategies that can be applied in the development of organic dragon fruit agribusiness in Wonogiri Regency. The basic method used is descriptive and analytical. Determination of the location of the study was carried out purposively, namely the Beji Makmur Farmers Group Association in Beji Village, Nguntoronadi District, Wonogiri Regency, the method of determining the Key Informants was chosen purposively. The types of data used are primary data and secondary data. The analytical method used is internal and external factor analysis, IFE and EFE matrix, IE matrix, SWOT matrix, and Analytical Hierarchy Process. The results of the research concluded that (1) The main factors of internal strength, namely marketing of organic dragon fruit have reached exports to Germany while the main weakness is the absence of the Beji Makmur Farmers Group Association secretariat, the main opportunity external factors namely the demand for organic dragon fruit in the form of fresh fruit while the main threat is erratic weather changes, (2) The alternative strategies for developing organic dragon fruit in Wonogiri Regency are SO, WO, ST, and WT strategy. (3) The development strategy priorities that can be applied in developing the Beji Makmur Farmers Group Association is to innovate by using radiation technology in the cultivation of organic dragon fruit so that productivity is more optimal.
\end{abstract}

Keywords: Analytical Hierarchy Process (AHP), Development Strategy, Dragon Fruit, Organic, SWOT

\section{PENDAHULUAN}

Subsektor tanaman hortikultura pada tahun 2017 tetap menjadi kontributor penting dalam pembangunan ekonomi nasional dengan peningkatan laju pertumbuhan PDB atas dasar harga berlaku sebesar 4,66\% dibandingkan dengan tahun sebelumnya(Direktorat Jenderal Hortikultura, 2017). Tanaman hortikultura di Indonesia dapat dikelompokkan menjadi empat yaitu sayur-sayuran, buah-buahan, tanaman hias, dan tanaman biofarmaka. Buah-buahan merupakan salah satu produk hortikultura yang sangat berpotensi untuk dikembangkan di Indonesia, salah satunya yaitu buah naga. Pengembangan agribisnis buah naga mempunyai prospek yang cerah untuk peluang ekspor dan pasarnya masih terbuka lebar serta memiliki potensi yang sangat baik untuk pasar di dalam negeri (Kristriandiny dan Slamet, 2016).Buah naga juga memiliki banyak khasiat untuk kesehatan tubuh di antaranya yaitu sebagai penyeimbang kadar gula darah, pencegah kanker usus, dan di samping itu dalam buah naga tidak terdapat lemak atau kolesterol (Oktavia, 2018).

Buah naga mulai dikenal di Indonesia sekitar pertengahan tahun 2000 (Rizal, 2015). Pada tahun 2010, pengembangan agribisnis buah naga mulai dikembangkan di Kabupaten Wonogiri tepatnya di Kelurahan Beji, Kecamatan Nguntoronadi oleh petani yang tergabung 
dalam Gabungan Kelompok Tani Beji Makmur. Buah naga yang dikembangkan merupakan buah naga organik. Keuntungan ekonomis yang diperoleh dari hasil penjualan buah naga organik lebih tinggi dibandingkan dengan nilai jual buah naga konvensional (non organik) (Ningsih et al., 2015). Pengembangan agribisnis buah naga organik di dukung oleh tiga subsistem utama agribisnis yang berjalan dengan baik, yaitu subsistem penyediaan sarana produksi, subsistem pemasaran dan subsistem penunjang (Faisal et al., 2014).

Tabel 1. Perkembangan Tanaman dan Produksi Buah Naga Organik pada Gabungan Kelompok Tani Beji Makmur, Keluruhan Beji

\begin{tabular}{rrrrr}
\hline \multirow{2}{*}{ No } & \multirow{2}{*}{ Tahun } & Jumlah Populasi & \multicolumn{2}{c}{ Produksi (buah) } \\
\cline { 4 - 5 } & & Buah naga (batang) & TargetBuah (kg) & Tercapai Buah (kg) \\
\hline 1 & $2010 / 2011$ & 15 & - & - \\
2 & $2011 / 2012$ & 150 & - & 20 \\
3 & $2012 / 2013$ & 450 & 25 & 37 \\
4 & $2013 / 2014$ & 2.500 & 50 & 65 \\
5 & $2014 / 2015$ & 5.000 & 250 & 450 \\
6 & $2015 / 2016$ & 10.000 & 1.000 & 1.100 \\
7 & $2016 / 2017$ & 15.000 & 1.500 & 1.450 \\
8 & $2017 / 2018$ & 16.000 & 1.800 & 1.680 \\
9 & $2018 / 2019$ & 17.000 & 2.000 & 1.800 \\
\hline
\end{tabular}

Sumber: Gapoktan Beji Makmur, 2019

Berdasarkan Tabel 1 diketahui bahwa perkembangan tanaman dan produksi buah naga organik pada Gabungan Kelompok Tani Beji Makmur menunjukkan peningkatan yang signifikan sehingga memiliki potensi untuk dikembangkan lebih lanjut. Akan tetapi, dengan pencapaian tersebut masih belum mampu memenuhi permintaan pasar. Oleh karena itu, diperlukan penelitian untuk mengetahui faktor internal dan faktor eksternal, merumuskan alternatif strategi, dan menentukan prioritas strategi yang tepat untuk pengembangan agribisnis buah naga organik pada Gabungan Kelompok Tani Beji Makmur.

\section{METODE PENELITIAN}

Metode dasar penelitian ini menggunakan metode deskriptif dan analitis (Nazir, 2014; Sugiyono, 2011).Penentuan lokasi penelitian dilakukan secara purposive pada Gabungan Kelompok Tani Beji Makmur di Kelurahan Beji, Kecamatan Nguntoronadi, Kabupaten Wonogiri. Penentuan key informan dipilih secara purposive yaitu orang yang benar-benar mempunyai pemahaman mengenai pengembangan agribisnis buah naga organik pada Gabungan Kelompok Tani Beji Makmurantara lain pengurus Gabungan Kelompok Tani Beji Makmur (Ketua, Wakil Ketua, Sekretaris, Bendahara), petani buah naga organik di Kelurahan Beji, konsumen, pesaing, dan pemerintah (Pemerintah Kelurahan Beji, Pemerintah Kecamatan Nguntoronadi, BPP Nguntoronadi, Dinas Pertanian dan Pangan Kabupaten Wonogiri) dengan total sebanyak 21 orang. Data yang digunakan dalam penelitian ini terdiri dari data primer dan data sekunder dengan teknik pengumpulan data yaitu wawancara, observasi, dan pencatatan. Analisis data yang dilakukan yaitu analisis faktor-faktor internal dan eksternal yang dapat diidentifikasikan menjadi kekuatan, kelemahan, peluang, dan ancaman yang kemudian dilakukan pembobotan dan pemberian rating menggunakan matriks 
IFE dan matriks EFE. Setelah itu dilakukan pencocokan menggunakan matriks IE untuk mengetahui di mana posisi pengembangan agribisnis buah naga organik. Analisis perumusan alternatif strategi pengembangan dapat menggunakan Matriks SWOT yang digambarkan dalam suatu matriks dengan 4 kemungkinan alternatif strategi yaitu strategi kekuatan-peluang (S-O strategies), strategi kelemahan-peluang (W-O strategies), strategi kekuatan-ancaman (S$\mathrm{T}$ strategies) dan strategi kelemahan-ancaman (W-T strategies). Setelah alternatif strategi dibuat maka untuk memprioritaskan alternatif strategi tersebut digunakan Analytical Hierarchy Process. AHP menghasilkan suatu strategi yang direkomendasikan melalui matriks SWOT yang dilakukan dengan pengolahan matriks perbandingan berpasangan. Hierarki yang terbentuk terdiri dari empat level yaitu pada level pertama atau puncak hierarki terdiri dari satu elemen yang disebut dengan fokus atau tujuan, yaitu sasaran keseluruhan yang bersifat luas. Pada level kedua terdiri dari empat grup dari SWOT, yaitu kekuatan (S), kelemahan $(\mathrm{W})$, peluang $(\mathrm{O})$, dan ancaman $(\mathrm{T})$. Pada level ketiga, terdiri dari faktor-faktor yang termasuk dalam masing-masing grup pada level kedua. Pada level keempat, terdiri dari alternatifalternatif strategi yang telah dianalisis dengan menggunakan matriks SWOT.

\section{HASIL DAN PEMBAHASAN}

\section{Analisis Faktor Internal dan Faktor Eksternal}

Berdasarkan analisis faktor internal dari pengembangan agribisnis buah naga organik pada Gabungan Kelompok Tani Beji Makmur menghasilkan faktor kekuatan dan faktor kelemahan. Faktor kekuatan yaitu (1) Struktur organisasi dan pembagian tugas dan fungsi yang jelas, (2) Sudah adanya pencatatan data dan keuangan, (3) Pengurus Gapoktan aktif dalam melakukan pendampingan pada anggota, (4) Pemasaran buah naga organik sudah mencapai ekspor ke Jerman, (5) Sudah memiliki SOP, sertifikat organik dan PIRT, (6) Proses budidaya mudah, (7) Gapoktan dapat membuat pupuk dan pestisida organik sendiri. Faktor kelemahan yaitu (1) Belum adanya sekretariat Gapoktan, (2) Keterbatasan modal usaha anggota, (3) Kurangnya motivasi anggota Gapoktan untuk mengembangkan ekonomi kreatif, (4) Promosi dan iklan kurang digencarkan, (5) Kurangnya informasi pasar untuk produk olahannya, (6) Produktivitasnya masih rendah.

Berdasarkan analisis faktor eksternal dari pengembangan agribisnis buah naga organik pada Gabungan Kelompok Tani Beji Makmur menghasilkan faktor peluang dan faktor ancaman. Faktor peluang yaitu (1) Permintaan buah naga organik dalam bentuk segar sangat tinggi, (2) Hubungan yang baik dengan eksportir, (3) Peluang industri hilir (produk olahan) terbuka luas, (4) Pengembangan buah naga organik mendapat perhatian khusus dari pemerintah, (5) PPL aktif dalam pemberdayaan masyarakat, (6) Perkembangan teknologi informasi membantu dalam pemasaran produk, (7) Kondisi tanah yang subur, (8) Masih terdapat lahan untuk meningkatkan produksi, (9) Sarana dan prasarana produksi mudah diperoleh, (10) Pesaing menjadi mitra. Faktor ancaman yaitu (1) Stabilitas politik di pemerintah tidak stabil, (2) Teknologi modern dalam pembudidayaan buah naga organik di daerah lain, (3) Perubahan cuaca yang tidak menentu, (4) Perkembangan hama dan penyakit, (5) Tanaman buah naga organik merupakan tanaman musiman sehingga tidak bisa berbuah sepanjang tahun. 
Setelah mengetahui hasil analisis faktor internal yang berupa kekuatan dan kelemahan serta faktor eksternal yang berupa peluang dan ancaman, selanjutnya dilakukan analisis matriks IFE dan matriks EFE untuk mengetahui seberapa kuat pengaruh dari masing-masing faktor internal dan faktor eksternal terhadap pengembangan agribisnis buah naga organik pada Gabungan Kelompok Tani Beji Makmur yang dapat dilihat pada Tabel 2 dan Tabel 3.

Tabel 2. Matriks Internal Factors Evaluation (IFE)

\begin{tabular}{|c|c|c|c|}
\hline Faktor Strategis Internal & Bobot & Rating & Skor \\
\hline \multicolumn{4}{|l|}{ Kekuatan } \\
\hline $\begin{array}{l}1 \text { Struktur organisasi dan pembagian tugas dan fungsi yang } \\
\text { jelas }\end{array}$ & 0,068 & 3 & 0,203 \\
\hline 2 Sudah adanya pencatatan data dan keuangan & 0,086 & 3 & 0,257 \\
\hline $\begin{array}{l}3 \text { Pengurus Gapoktan aktif dalam melakukan pendampingan } \\
\text { pada anggota }\end{array}$ & 0,060 & 4 & 0,238 \\
\hline $\begin{array}{l}4 \text { Pemasaran buah naga organik sudah mencapai ekspor ke } \\
\text { Jerman }\end{array}$ & 0,069 & 4 & 0,275 \\
\hline 5 Sudah memiliki SOP, sertifikat organik, dan PIRT & 0,065 & 4 & 0,262 \\
\hline 6 Proses budidaya mudah & 0,101 & 2 & 0,201 \\
\hline $\begin{array}{l}7 \text { Gapoktan dapat membuat pupuk dan pestisida organik } \\
\text { sendiri }\end{array}$ & 0,073 & 3 & 0,220 \\
\hline \multicolumn{4}{|l|}{ Kelemahan } \\
\hline 1 Belum adanya sekretariat Gapoktan & 0,105 & 1 & 0,105 \\
\hline 2 Keterbatasan modal usaha anggota Gapoktan & 0,061 & 4 & 0,245 \\
\hline $\begin{array}{l}3 \text { Kurangnya motivasi anggota Gapoktan untuk } \\
\text { mengembangkan ekonomi kreatif }\end{array}$ & 0,060 & 4 & 0,242 \\
\hline 4 Promosi dan iklan kurang digencarkan & 0,097 & 2 & 0,193 \\
\hline 5 Kurangnya informasi pasar untuk produk olahannya & 0,088 & 3 & 0,265 \\
\hline 6 Produktivitasnya masih rendah & 0,067 & 4 & 0,267 \\
\hline Jumlah & $\mathbf{1 , 0 0 0}$ & & 2,974 \\
\hline
\end{tabular}

Sumber : Data Primer diolah, 2019

Berdasarkan Tabel 2 diketahui bahwa kekuatan utama dari pengembangan agribisnis buah naga organik pada Gabungan Kelompok Tani Beji Makmur terletak pada pemasaran buah naga organik yang sudah mencapai ekspor ke Jerman dengan skor sebesar 0,275.Kelemahan utama dari pengembangan agribisnis buah naga organik pada Gabungan Kelompok Tani Beji Makmur dengan skor terendah sebesar 0,105 adalah belum adanya sekretariat Gapoktan. Total skor yang diperoleh dari faktor internal pengembangan agribisnis buah naga organik pada Gabungan Kelompok Tani Beji Makmur sebesar 2,974. Menurut David (2013), total skor yang berada di atas 2,5 menunjukkan bahwa kondisi dari organisasi kuat dilihat dari sisi internal.

Tabel 3. Matriks External Factors Evaluation (EFE)

\begin{tabular}{|c|c|c|c|c|}
\hline & Faktor Strategis Eksternal & Bobot & Rating & Skor \\
\hline \multicolumn{5}{|c|}{ Peluang } \\
\hline 1 & $\begin{array}{l}\text { Permintaan buah naga organik dalam bentuk buah segar } \\
\text { sangat tinggi }\end{array}$ & 0,053 & 4 & 0,212 \\
\hline 2 & Hubungan yang baik dengan eksportir & 0,052 & 4 & 0,208 \\
\hline 3 & Peluang industri hilir (produk olahan) terbuka lebar/luas & 0,060 & 3 & 0,180 \\
\hline
\end{tabular}


4 Pengembangan buah naga organik mendapat perhatian $\quad 0,080 \quad 2 \quad 0,160$

khusus dari pemerintah

$5 \quad$ PPL aktif dalam pemberdayaan masyarakat $\quad 0,052 \quad 4 \quad 0,207$

$\begin{array}{lllll}6 & \text { Perkembangan teknologi informasi membantu pemasaran } & 0,078 & 2 & 0,157\end{array}$

$\begin{array}{lllll}7 & \text { Kondisi tanah yang subur } & 0,073 & 2 & 0,147\end{array}$

8 Masih terdapat lahan untuk meningkatkan produksi $\quad 0,060 \quad 3 \quad 0,180$

9 Sarana dan prasarana produksi mudah diperoleh $\quad 0,069 \quad 3 \quad 0,206$

10 Pesaing menjadi mitra $\quad 0,052 \quad 3 \quad 0,156$

Ancaman

$1 \quad$ Stabilitas politik di pemerintah tidak stabil $\quad 0,094 \quad 1 \quad 0,094$

2 Teknologi modern dalam pembudidayaan buah naga $\quad 0,071 \quad 2 \quad 0,143$ organik di daerah lain

$3 \quad$ Perubahan cuaca yang tidak menentu $\quad 0,068 \quad 3 \quad 0,203$

$\begin{array}{lllll}4 & \text { Perkembangan hama dan penyakit } & 0,073 & 2 & 0,146\end{array}$

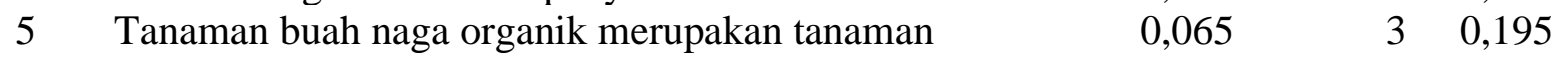
musiman sehingga tidak bisa berbuah sepanjang tahun

\begin{tabular}{lll}
\hline Jumlah & $\mathbf{1 , 0 0 0}$ & $\mathbf{2 , 5 9 3}$ \\
\hline
\end{tabular}

Sumber: Data Primer diolah, 2019

Berdasarkan Tabel 3 diketahui bahwa peluang utama pengembangan agribisnis buah naga organik pada Gabungan Kelompok Tani Beji Makmur adalah permintaan buah naga organik dalam bentuk buah segar sangat tinggi dengan skor sebesar 0,212.Ancaman utama pada pengembangan agribisnis buah naga organik pada Gabungan Kelompok Tani Beji Makmur adalah perubahan cuaca yang tidak menentu sebesar 0,203. Nilai total skor matriks EFE sebesar 2,593. Nilai total skor tersebut berada di atas 2,5 sehingga pengembangan agribisnis buah naga organik memiliki peluang yang menguntungkan dan mampu menghindari ancaman yang dimiliki. Hal ini sesuai dengan Kustiawari et al. (2014) yang mengindikasikan bahwa pengembangan agribisnis buah naga organik tergolong kuat dalam memanfaatkan peluang yang sudah ada untuk meminimalisir ancaman eksternal.

Berdasarkan analisis matriks IFE dan EFE yang telah dilakukan diperoleh koordinat $X=2,974$ dan nilai koordinat $Y=2,593$. Menurut David (2013) bahwa skor yang berada diantar 2,00-2,99 dianggap sedang. Pada analisis matriks IE menunjukkan posisi pengembangan agribisnis buah naga organik pada Gabungan Kelompok Tani Beji Makmur berada di Sel V yang menggambarkan posisi pengembangannya adalah menjaga dan mempertahankan (hold and maintenance).Pada sel V menurut David (2009), dua strategi yang paling banyak digunakan adalah penetrasi pasar dan pengembangan produk.

\section{Analisis SWOT}

Analisis matriks SWOT digunakan untuk merumuskan alternatif strategi pengembangan agribisnis buah naga organik pada Gabungan Kelompok Tani Beji Makmur berdasarkan analisis faktor internal dan eksternal. Beberapa alternatif strategi yang dapat dikembangkan melalui matriks SWOT adalah strategi SO (Strenght-Opportunities), strategi WO (WeaknessOpportunities), strategi ST (Strenght-Threat), dan strategi WT (Weakness-Threat). 
Tabel 4. Analisis Alternatif Strategi Pengembangan Agribisnis Buah Naga Organik pada Gabungan Kelompok Tani Beji Makmur

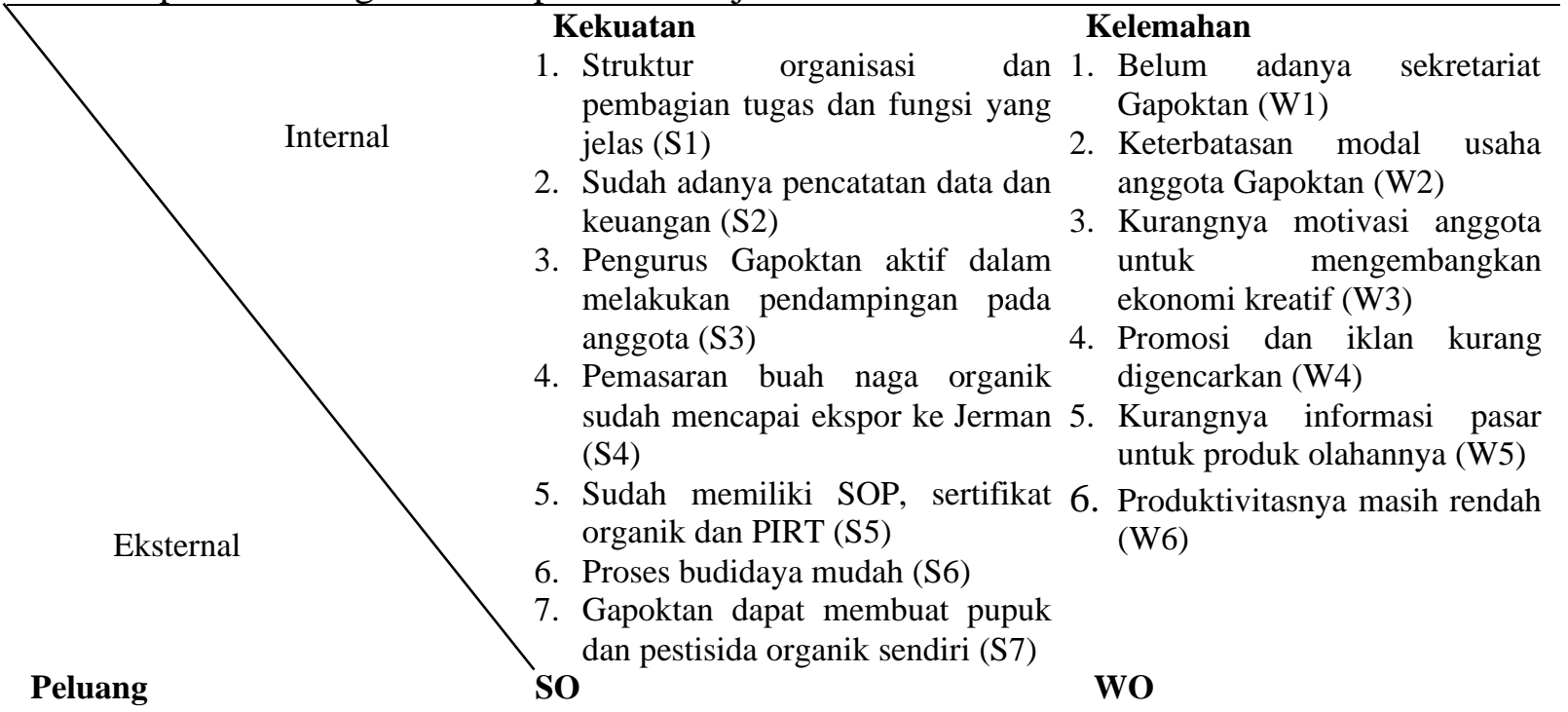

1. Permintaan buah naga organik 1 dalam bentuk buah segar sangat tinggi (O1)

2. Hubungan yang baik dengan eksportir $(\mathrm{O} 2)$

3. Peluang industri hilir (produk olahan) terbuka lebar/luas (O3)

1. Mengembangkan meningkatkan kualitas dan kuantitas buah naga organik dengan memanfaatkan potensi lahan yang masih tersedia (S4, S5, S6, S7, O1, O2, O3, O4, O7, O8)

2. Merintis dan mengembangkan industri rumah tangga dengan mengembangkan produk buah naga organik menjadi produkproduk olahan $(\mathrm{S} 3, \mathrm{~S} 5, \mathrm{O} 3, \mathrm{O} 4$, O5, 06, O9)

5. PPL aktif dalam pemberdayaan masyarakat (O5)

6. Perkembangan teknologi informasi membantu dalam pemasaran (O6)

7. Kondisi tanah yang subur $(\mathrm{O} 7)$

8. Masih terdapat lahan untuk meningkatkan produksi (O8)

9. Sarana dan prasarana produksi mudah diperoleh (O9)

10. Pesaing menjadi mitra(O10)

Ancaman

1. Stabilitas politik di pemerintah tidak stabil (T1)

2. Teknologi modern dalam pembudidayaan buah naga organik di daerah lain (T2)

ST

1. Meningkatkan kelembagaan Gapoktan terkait dengan pengembangan agribisnis buah naga organik (S1, S2, S3, S7, T1, T2)

2. Meningkatkan kemampuan dalam mengantisipasi terjadinya pergantian musim (pancaroba) yang ekstrem (S6, T3, T4, T5)
Optimalisasi pemberdayaan, pendampingan, dan pelatihan pengurus dan anggota Gapoktan guna meningkatkan produktivitasnya (W1, W3, W4, W5, W6, O1,O3,O5, O6)

2. Meningkatkan dan memperluas jaringan pemasaran produk olahan dari buah naga organik dengan memanfaatkan teknologi informasi serta pendampingan dari pihak pemerintah/dinas terkait untuk meningkatkan pendapatan (W2, W4, W5, W6, O2, O3, O4, O10)

WT

. Melakukan inovasi dengan menggunakan teknologi penyinaran dalam pembudidayaan buah naga organik agar produktivitasnya lebih optimal (O2, O6, T2, T3, T4, T5)

\section{menentu (T3)}

4. Perkembangan hama dan penyakit (T4)

5. Tanaman buah naga organik merupakan tanaman musiman sehingga tidak bisa berbuah sepanjang tahun (T5)

Sumber : Data Primer diolah, 2019 
Berdasarkan Tabel 4 diketahui bahwa alternatif strategi yang dapat diambil untuk mencapai pengembangan agribisnis buah naga organik pada Gabungan Kelompok Tani Beji Makmur secara berkelanjutan. Alternatif strategi pengembangan agribisnis buah naga organik pada Gabungan Kelompok Tani Beji Makmur yang dihasilkan dari analisis matriks SWOT antara lain sebagai berikut.

\section{Strategi SO}

Meningkatkan kualitas dan kuantitas buah naga organik dengan memanfaatkan potensi lahan yang masih tersedia

Strategi meningkatkan kualitas dan kuantitas buah naga organik pada Gabungan Kelompok Tani Beji Makmur dapat dilakukan dengan memerhatikan SOP (Standard Operating Procedure) dalam proses pembudidayaan buah naga organik dan memperluas lahan budidaya dengan memanfaatkan lahan potensial yang masih tersedia untuk areal pembudidayaan buah naga organik, sehingga diharapkan di masa yang akan datang akan mampu meningkatkan kuantitas buah naga organik pada Gabungan Kelompok Tani Beji Makmur.

Merintis dan mengembangkan industri rumah tangga dengan mengembangkan produk buah naga organik menjadi produk-produk olahan

Produk olahan buah naga akan meningkatkan nilai tambah produk, menambah daya tahan produk, serta menambah keberagaman makanan olahan dari buah naga organik .Pembuatan produk olahan ini merupakan suatu solusi untuk meningkatkan nilai tambah hasil panen dan memperluas pangsa pasar sehingga pendapatan dan kesejahteraan petani buah naga organik yang tergabung dalam Gabungan Kelompok Tani Beji Makmur dapat meningkat.

\section{Strategi WO}

Optimalisasi pemberdayaan, pendampingan, dan pelatihan pengurus dan anggota Gapoktan guna meningkatkan produktivitasnya.

Adanya pelatihan dan pendampingan diharapkan mampu meningkatkan kualitas dan produktivitas pengurus maupun anggota Gabungan Kelompok Tani Beji Makmur. Peningkatan kualitas dan produktivitas dilakukan dengan menjalin kerja sama dengan pemangku kebijakan setempat misalnya dengan pengadaan pelatihan-pelatihan.

Meningkatkan dan memperluas jaringan pemasaran produk olahan dari buah naga organik dengan memanfaatkan teknologi informasi serta pendampingan dari pihak pemerintah/dinas terkait untuk meningkatkan pendapatan.

Peningkatan dan perluasan jaringan pemasaran dari berbagai produk olahan buah naga organik dapat dilakukan melalui kegiatan-kegiatan pengenalan produk unggulan lokal yang biasanya merupakan kegiatan dari pemerintah setempat yang dilakukan pada suatu waktu tertentu seperti pameran, bazar, expo, dan kegiatan lainnya.

\section{Strategi ST}

Meningkatkan sistem kelembagaan Gapoktan terkait dengan pengembangan agribisnis buah naga organik. 
Peningkatan sistem kelembagaan Gabungan Kelompok Tani Beji Makmur dapat dilakukan dengan beberapa cara yaitu pembinaan dan pemantauan dari PPL Kelurahan Beji harus dilakukan untuk memonitor kegiatan-kegiatan yang dilakukan oleh Gabungan Kelompok Tani Beji Makmur, meningkatkan koordinasi dan kerja sama baik antar pengurus, pengurus ke anggota maupun antar anggota, dan mempertanggungjawabkan tugas dan fungsi masing-masing pengurus Gabungan Kelompok Tani Beji Makmur.

Meningkatkan kemampuan dalam mengantisipasi terjadinya pergantian musim (pancaroba) yang ekstrem.

Meningkatkan kemampuan dalam mengantisipasi terjadinya pergantian musim (pancaroba) yang ekstrem dapat dilakukan dengan persiapan penyediaan air berlebih ketika musim kemarau akan datang, mempersiapkan lahan ketika musim hujan akan datang agar air hujan tidak menggenang misalnya membuat jalur irigasi, dan membuat pestisida organik untuk membasmi hama dan penyakit yang menyerang buah naga organik.

\section{Strategi WT}

Melakukan inovasi dengan menggunakan teknologi penyinaran dalam pembudidayaan buah naga organik agar produktivitasnya lebih optimal.

Diperlukan inovasi baru untuk membuat buah naga organik dapat berbuah sepanjang tahun sehingga mampu memenuhi permintaan konsumen yaitu dengan penerapan teknologi pengaturan pembuahan menggunakan lampu penerangan listrik di kebun buah naga organik. Memberi tambahan lampu/penerangan pada tanaman buah naga organik akan menambah cahaya untuk merangsang bunga pada buah naga organik, sehingga buah naga organik bisa berbuah sepanjang tahun

\section{Analisis AHP}

Analisis AHP (Analytical Hierarchy Process) digunakan untuk menentukan prioritas alternatif strategi dalam pengembangan agribisnis buah naga organik pada Gabungan Kelompok Tani Beji Makmur. Penilaian AHP dilakukan oleh Ketua Gabungan Kelompok Tani Beji Makmur yaitu Bapak Sularto yang dianggap memahami kondisi pengembangan agribisnis buah naga organik pada Gabungan Kelompok Tani Beji Makmur di Kelurahan Beji Kabupaten Wonogiri. Hasil penilaian tersebut dapat dilihat pada Tabel 5.

Tabel 5. Penilaian dalam Penentuan Prioritas Strategi Pengembangan Agribisnis Buah Naga Organik pada Gabungan Kelompok Tani Beji Makmur

\begin{tabular}{clcc}
\hline Strategi & \multicolumn{1}{c}{ Alternatif Strategi } & Bobot & Prioritas \\
\hline S-O & $\begin{array}{l}\text { Mengembangkan dan meningkatkan kualitas dan } \\
\text { kuantitas buah naga organik dengan memanfaatkan } \\
\text { potensi lahan yang masih tersedia }\end{array}$ & 4,2474 & 2 \\
S-O & $\begin{array}{l}\text { Merintis dan mengembangkan industri rumah tangga } \\
\text { dengan mengembangkan produk buah naga organik } \\
\text { menjadi produk-produk olahan }\end{array}$ & 3,7052 & 5 \\
W-O & $\begin{array}{l}\text { Optimalisasi pemberdayaan, pendampingan, dan } \\
\text { pelatihan pengurus dan anggota Gapoktan guna }\end{array}$ & 3,8558 & 4
\end{tabular}




\begin{tabular}{|c|c|c|}
\hline $\mathrm{W}-\mathrm{O}$ & $\begin{array}{l}\text { meningkatkan produktivitasnya } \\
\text { Meningkatkan dan memperluas jaringan pemasaran } \\
\text { produk olahan dari buah naga organik dengan } \\
\text { memanfaatkan teknologi informasi serta pendampingan } \\
\text { dari pihak pemerintah/dinas terkait untuk meningkatkan } \\
\text { pendapatan }\end{array}$ & 3,6019 \\
\hline S-T & $\begin{array}{l}\text { Meningkatkan sistem kelembagaan Gapoktan terkait } \\
\text { dengan pengembangan agribisnis buah naga organik }\end{array}$ & 4,1705 \\
\hline S-T & $\begin{array}{l}\text { Meningkatkan kemampuan dalam mengantisipasi } \\
\text { terjadinya pergantian musim (pancaroba) yang ekstrem }\end{array}$ & 3,5215 \\
\hline W-T & $\begin{array}{l}\text { Melakukan inovasi dengan menggunakan teknologi } \\
\text { penyinaran dalam pembudidayaan buah naga organik } \\
\text { agar produktivitasnya lebih optimal }\end{array}$ & 4,5207 \\
\hline
\end{tabular}

Berdasarkan Tabel 5 dapat diketahui bahwa dari ketujuh alternatif strategi yang telah dirumuskan, strategi yang menjadi prioritas utama adalah melakukan inovasi dengan menggunakan teknologi penyinaran dalam pembudidayaan buah naga organik agar produktivitasnya lebih optimal dengan nilai prioritas sebesar 4,5207. Strategi tersebut diprioritaskan untuk dilaksanakan terlebih dahulu karena untuk membuat buah naga organik dapat berbuah sepanjang tahun sehingga mampu memenuhi permintaan konsumen. Penerapan teknologi pengaturan pembuahan menggunakan lampu penerangan listrik di kebun buah naga organik akan menambah cahaya untuk merangsang perkembangan bunga pada malam hari. Teknologi penyinaran biasanya dilakukan di luar musim panen (April-September) dengan memasang lampu-lampu di sekitar tanaman buah naga organik dengan sistem 4-1 (satu lampu untuk menyinari 4 pohon) atau sistem 2-1 (satu lampu dengan 2 pohon) atau kombinasi dari dua sistem tersebut. Waktu penyinaran dilakukan pada jam 5 sore hingga jam 6 pagi untuk menjaga suhu tetap pada 26o-36oC. Daya yang dibutuhkan untuk lampu penyinaran tergantung luas lahan tanah dan pohon buah naga organik, pemasangan lampu diletakkan di antara pohon buah naga organik agar masing-masing sisi pohon buah naga organik dapat penyinaran dengan maksimal. Lampu yang digunakan yaitu lampu merek visalux daya 12-15 watt, jika kurang terang hasilnya kurang maksimal, begitu juga jika berlebih batang pohon naga akan menguning (Santoso, 2013).

Prioritas strategi yang kedua adalah mengembangkan dan meningkatkan kualitas dan kuantitas buah naga organik dengan memanfaatkan potensi lahan yang masih tersedia dengan nilai prioritas sebesar 4,2474. Hal ini dikarenakan kualitas dan kuantitas buah naga organik berhubungan dengan kesediaan konsumen untuk membeli buah naga organik dalam jumlah yang tinggi. Pemanfaatan lahan secara optimal diharapkan di masa yang akan datang akan mampu meningkatkan kuantitas buah naga organik pada Gabungan Kelompok Tani Beji Makmur. Prioritas strategi yang ketiga adalah meningkatkan sistem kelembagaan Gapoktan terkait dengan pengembangan agribisnis buah naga organik dengan nilai prioritas sebesar 4,1705. Adanya kelembagaan Gabungan Kelompok Tani Beji Makmur harapannya mampu meningkatkan pendapatan dan perekonomian bagi petani buah naga organik yang tergabung di dalamnya serta mampu mewujudkan kemandirian petani di era ekonomi kreatif. Peningkatan sistem kelembagaan Gabungan Kelompok Tani Beji Makmur perlu dilakukan untuk mencapai visi dan misi yang diinginkan. Peningkatan sistem kelembagaan Gabungan 
Kelompok Tani Beji Makmur dapat dilakukan dengan beberapa cara yaitu pembinaan dan pemantauan dari PPL Kelurahan Beji harus dilakukan untuk memonitor kegiatan-kegiatan yang dilakukan oleh Gabungan Kelompok Tani Beji Makmur, meningkatkan koordinasi dan kerja sama baik antar pengurus, pengurus ke anggota maupun antar anggota, dan mempertanggungjawabkan tugas dan fungsi masing-masing.

Prioritas strategi yang keempat adalah optimalisasi pemberdayaan, pendampingan, dan pelatihan pengurus dan anggota Gapoktan guna meningkatkan produktivitas dengan nilai prioritas sebesar 3,8558. Strategi yang kelima adalah merintis dan mengembangkan industri rumah tangga dengan mengembangkan produk buah naga organik menjadi produk-produk olahan dengan nilai prioritas sebesar 3,7052. Strategi yang selanjutnya adalah meningkatkan dan memperluas jaringan pemasaran produk olahan dari buah naga organik dengan memanfaatkan teknologi informasi serta pendampingan dari pihak pemerintah/dinas terkait untuk meningkatkan pendapatan dengan nilai prioritas sebesar 3,6019. Selanjutnya, strategi terakhir yang dapat dilakukan adalah meningkatkan kemampuan dalam mengantisipasi terjadinya pergantian musim (pancaroba) yang ekstrem dengan nilai prioritas sebesar 3,5215.

\section{KESIMPULAN DAN SARAN}

\section{Kesimpulan}

Berdasarkan hasil penelitian dapat diperoleh beberapa kesimpulan sebagai berikut.

1. Faktor utama lingkungan internal dan eksternal yang memengaruhi pengembangan agribisnis buah naga organik pada Gabungan Kelompok Tani Beji Makmur di Kelurahan Beji, Kabupaten Wonogiri, yaitu:

a. Faktor internal pada pengembangan agribisnis buah naga organik pada Gabungan Kelompok Tani Beji Makmur yang menjadi kekuatan utama adalah pemasaran buah naga organik sudah mencapai ekspor ke Jerman, sedangkan kelemahan utama adalah belum adanya sekretariat Gapoktan.

b. Faktor eksternal pada pengembangan agribisnis buah naga organik pada Gabungan Kelompok Tani Beji Makmur yang menjadi peluang utama adalah permintaan buah naga organik dalam bentuk buah segar sangat tinggi, sedangkan ancaman utama adalah perubahan cuaca yang tidak menentu.

2. Alternatif strategi pengembangan agribisnis buah naga organik pada Gabungan Kelompok Tani Beji Makmur yaitu:

a. Strategi 1: Mengembangkan dan meningkatkan kualitas dan kuantitas buah naga organik dengan memanfaatkan potensi lahan yang masih tersedia

b. Strategi2:Merintis dan mengembangkan industri rumah tangga dengan mengembangkan produk buah naga organik menjadi produk-produk olahan

c. Strategi 3: Optimalisasi pemberdayaan, pendampingan, dan pelatihan pengurus dan anggota Gapoktan guna meningkatkan produktivitasnya 
d. Strategi 4: Meningkatkan dan memperluas jaringan pemasaran produk olahan dari buah naga organik dengan memanfaatkan teknologi informasi serta pendampingan dari pihak pemerintah/dinas terkait untuk meningkatkan pendapatan

e. Strategi 5: Meningkatkan sistem kelembagaan Gapoktan terkait dengan pengembangan agribisnis buah naga organik

f. Strategi 6: Meningkatkan kemampuan dalam mengantisipasi terjadinya pergantian musim (pancaroba) yang ekstrem

g. Strategi 7: Melakukan inovasi dengan menggunakan teknologi penyinaran dalam pembudidayaan buah naga organik agar produktivitasnya lebih optimal

3. Prioritas strategi pengembangan agribisnis buah naga organik pada Gabungan Kelompok Tani Beji Makmur adalah melakukan inovasi dengan menggunakan teknologi penyinaran dalam pembudidayaan buah naga organik agar produktivitasnya lebih optimal.

\section{Saran}

Berdasarkan hasil penelitian yang telah dilakukan, saran yang dapat diberikan yaitu sebagai berikut.

1. Gabungan Kelompok Tani Beji Makmur sebaiknya segera merealisasikan dan mengkoordinasikan dengan PT MIO mengenai teknik operasional strategi yang diprioritaskan yaitu menggunakan teknologi penyinaran dalam pembudidayaan buah naga organik untuk merangsang pertumbuhan dan perkembangan buah naga organik sehingga mampu berbuah di luar musim.

2. Gabungan Kelompok Tani Beji Makmur perlu membuat account atau website khusus untuk meningkatkan dan memperluas jaringan pemasaran buah naga organik baik dalam bentuk segar maupun olahannya.

3. Gabungan Kelompok Tani Beji Makmur perlu memperhatikan SOP (Standard Operating Procedure) dalam proses pembudidayaan buah naga organik dan memanfaatkan lahan potensial yang masih tersedia guna meningkatkan kualitas dan kuantitas buah naga organik.

4. Gabungan Kelompok Tani Beji Makmur sebaiknya aktif dalam mengikuti pelatihanpelatihan yang berhubungan dengan pengembangan agribisnis buah naga organik sehingga mampu meningkatkan produktivitasnya.

5. Gabungan Kelompok Tani Beji Makmur sebaiknya lebih responsif terhadap pergantian musim yang ekstrem dengan cara menyiapkan penampungan air dan membuat saluran irigasi pada musim penghujan guna menjaga ketersediaan air pada musim kemarau.

\section{DAFTAR PUSTAKA}

David, F. (2009). Strategic Management, Concepts \& Cases Twelfth Edition. England : Pearson Education Limited.

David, F. (2013). Strategic Management, Concepts \& Cases Fourteenth Edition. England : Pearson Education Limited. 
Direktorat Jenderal Hortikultura. (2017). Laporan Kinerja Direktorat Jenderal Hortikultura. Jakarta : Kementerian Pertanian RI.

Faisal, M., Syaiful H., dan Arifudin. (2014). Strategi Pengembangan Agribisnis Buah Naga di Pulau Bengkalis. Jurnal Jom Faperta, 1 (2).

Kristriandiny, O., dan Slamet S. (2016). Budidaya Buah Naga Putih (Hylocereus undatus) di Sleman, Yogyakarta : Panen dan Pascapanen. Jurnal Agrohorti, 4 (1), 1-8.

Kustiawati, N., Halimatus S., dan HermanF. (2014). Model of Development From Organic Farming Dragon Fruit : An Implementation Of Sustainable Agriculture. International Journal Natural and Applied Sciences, 1 (1).

Nazir, M. (2014). Metode Penelitian. Jakarta : Ghalia Indonesia.

Ningsih, K., Herman F., dan Halimatus S. (2015). Keragaan Usahatani dan Pemasaran Buah Naga Organik. Jurnal Agriekonomika, 4 (2).

Oktavia, D. (2018). Buah Naga Bukan Sekedar Buah dari Eksistensi hingga Strategi : Penguatan Buah Naga dalam Menurunkan Tingkat Kemiskinan dan Meningkatkan Perekonomian Masyarakat (Studi Kasus Kecamatan Genteng Kabupaten Banyuwangi). Jurnal Aghinya Stiesnu Bengkulu, 1 (1).

Rizal, M. (2015). Prospek Pengembangan Buah Naga (Hylocereus costaricensis) di Kabupaten Kutai Kartanegara, Kalimantan Timur. Jurnal PROS SEM NAS MASY BIODIV INDON,1 (4), 884-888.

Santoso. (2013). Budidaya Buah Naga Organik di Pekarangan berdasarkan Pengalaman Petani di Kabupaten Malang. Jurnal Iptek Hortikultura, 1 (8).

Sugiyono. (2011). Metode Penelitian Kuantitatif, Kualitatif, dan R\&D. Bandung : Alfabeta.

Tim Gapoktan Beji Makmur. (2019). Profil Gapoktan Beji Makmur. Wonogiri : Gapoktan Beji Makmur. 